\title{
Pros

\section{LA AUTODERRISIÓN EN LA OBRA DE FERNANDO IWASAKI}

Bernat Castany Prado

Universitat de Barcelona

\section{LA AUTODERRISIÓN COMO TRAICIÓN}

Con los términos "autoderrisión" (del francés, autodérision) o "autodeprecación" (del inglés, self-deprecation) ${ }^{2}$ nos referimos a la técnica retórica que consiste en la confesión o exhibición, por parte de un hablante, de sucesos o aspectos ridículos asociados a su persona, con el objetivo de atenuar su pretendida superioridad en tanto que crítico o satírico y propiciar, así, la identificación o conexión con sus interlocutores ${ }^{3}$. No queremos, sin embargo, reducirnos a estudiar la autoderrisión en la obra de Fernando Iwasaki como una mera estrategia retórica, sino, antes bien, tratar de vislumbrar una significación más profunda. Ciertamente, creemos, con los principales representantes de la estilística, que los tropos literarios o retóricos no son meramente neutros, sino que normalmente

\footnotetext{
${ }^{1}$ Este artículo es el desarrollo de una ponencia titulada "Autoderrisión y autoficción en la obra de Fernando Iwasaki", presentada en las Jornadas internacionales sobre narrativa actual "La autoficción hispánica en el siglo XXI", que se celebraron del 7 al 9 de octubre de 2013, en la Universidad de Alcalá.

2 A pesar de ser una traducción directa del francés, el término "autoderrisión" es perfectamente válido en español, pues puede hacerse derivar del sustantivo desusado "derrisión", que significa, según el DRAE 'irrisión' o 'escarnio'. He descartado el término "autoparodia" o "parodia del yo", acuñado por Jean Paul Richter, en su Introducción a la estética, de 1800, así como "autoironía", porque la parodia y la ironía son sólo dos de las muchas modalidades de la irrisión, cuando mi intención es tratar de abarcar el mayor número posible.

${ }^{3}$ Según Bouquet y Riffault (2010), la autoderrisión facilita las relaciones con los demás y reconforta ante la adversidad.
} 
expresan (al articularse con otros elementos narrativos, estilísticos o temáticos) una determinada filosofía o sensibilidad. Un modo de trascender la interpretación meramente formal de la autoderrisión o autodeprecación es tomar conciencia de sus potencialidades simbólicas. Si bien es cierto que existen casos en los que la autoderrisión es utilizada como una estrategia para ridiculizar "desde dentro" a un colectivo en particular, en la mayor parte de los casos tenemos la sensación de que el autor, narrador o personaje que se ríe de sí mismo se está riendo también de la humanidad en su conjunto, de la que él no sería más que un ejemplar. En dichas ocasiones, el discurso autoderrisorio se nos revela como un discurso filosófico o antropológico de alcance universal. Por otra parte, la autoderrisión no se da siempre de forma directa, esto es, en primera persona, sino también de forma indirecta o, digámoslo así, "por poderes" personajes, situaciones, acciones o reflexiones en las que el autor no se presenta como un ser superior respecto del objeto de su risa, como sucede en la sátira, sino como un ser afectado por los mismos rasgos risibles. Podemos afirmar pues, que la autoderrisión es un rasgo omnipresente en la literatura, la filosofía e, incluso, la teología occidentales. Este hecho es el que nos lleva a sospechar que la autoderrisión no es una mera estrategia retórica, sino la expresión de algo mucho más profundo.

En el ámbito literario nos encontramos, por ejemplo, con los trágicos griegos, muchos de cuyos monólogos pueden verse como reflexiones amargamente autoderrisorias acerca del carácter irónicamente trágico de la existencia; con Luciano de Samósata, en cuyos opúsculos se ríe de la estupidez y presunción de los hombres, ya sea directamente (El cínico), ya sea indirectamente, a través del género de la adoxografía o elogio desmesurado de realidades despreciables o risibles (Elogio de las moscas); con Erasmo, en cuyo Elogio de la locura el cínico autoelogio de la locura supone, entre otras cosas, una autoburla de la propia condición humana; con Montaigne, quien en sus Ensayos nos habla en tono desenfadado tanto de sus defectos físicos como de su indecisión, inconsistencia, mala memoria, tacañería o lentitud de espíritu; con Shakespeare, muchos de cuyos personajes se ríen de la inconstancia, pequeñez e ignorancia de esa "quintaesencia del polvo" que es el hombre; con Cervantes, cuyo héroe simboliza, en parte, la humanidad misma riéndose de un fanatismo que vive encerrado en los libros, de espaldas a la realidad y deseoso de imponer violentamente sus fantasías; o con Borges, en cuyos ensayos y relatos humilla festivamente las pretensiones cognoscitivas y existenciales de los hombres, reservándose siempre para sí mismo algún comentario autoirónico.

También en la historia de la filosofía nos encontramos con numerosos ejemplos de autoderrisión. El filósofo griego de origen escita conocido como Anacarsis (s. vı a. C.), no solo fue un modelo para los futuros filósofos cínicos, sino que también dio lugar a un personaje literario que se caracterizaba por

\footnotetext{
${ }^{4}$ Montaigne se reiría de sí mismo (y de la humanidad, que en él se cifra) directamente, mientras que Luciano, Erasmo, Shakespeare, Cervantes o Borges lo harían a través de sus personajes y de aquello que les sucede.
} 
su sentido del humor, en muchas ocasiones autodenigrativo ${ }^{5}$. Por su parte, Sócrates será presentado como epítome del sabio en virtud de su conciencia del carácter irremediablemente estulto del ser humano, y de sí mismo, cifrado en su autoirónico "sólo sé que no sé nada". Piénsese también en los filósofos cínicos, muchas de cuyas anécdotas o chreía, como, por ejemplo, masturbarse en públi$\mathrm{co}$, chocarse con la gente que sale del teatro, caminar desnudo o comer huesos como un perro, tenían un componente claramente autoderrisorio ${ }^{6}$. Finalmente, los autores pertenecientes a la tradición escéptica, desde Pirrón hasta Borges, pasando por Sexto Empírico, Petrarca, Erasmo, Montaigne o David Hume, se burlan en sus propias personas del carácter ignaro de todo ser humano7.

También en el ámbito religioso nos encontramos con numerosos ejemplos de autoderrisión. En la llíada, Homero afirma que "todos los dioses ríen a la vez, descaradamente, de las desgracias de los hombres" (lib. 1, v. 561). Por su parte, el autor del libro de Job hace que Dios se burle sarcásticamente de Job y de sus amigos, que son símbolo del ser humano, que pretende vanamente comprender sus designios:

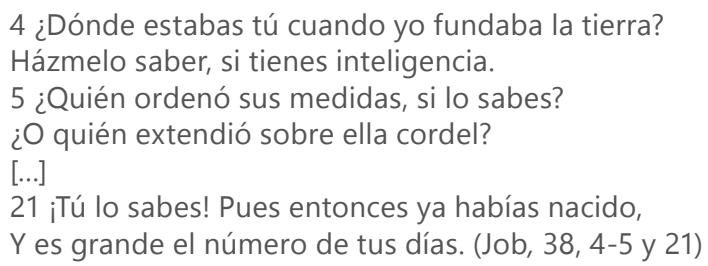

Algo semejante sucede en el Eclesiastés, donde el autor, claramente influido por el epicureísmo y el escepticismo helenísticos, insiste en la insignificancia del hombre, lo que supone a su vez una burla autodeprecativa de su propia persona. También en los Salmos (2, v. 4) se dirá: "El que se sienta en los cielos se sonríe, Yahvé se burla de ellos". Dicha tradición continuará en numerosos sermones medievales; en san Francisco de Asís, que se presentaba a sí mismo como "bufón de Dios" y fue protagonista de anécdotas autodenigrativas que lo hermanaban con los cínicos grecolatinos; en la doctrina de la docta ignorancia de Nicolás de Cusa, autor de unos Diálogos del idiota; en la philosophia Christi de Erasmo, contenida tanto en el Elogio de la locura ${ }^{8}$, como en los Ensayos de Montaigne, e, incluso, en la obra crítica de Kant.

\footnotetext{
${ }^{5}$ Véase al respecto "El acento escita: Anacarsis y los cínicos", de Martin (2000: 182-207).

${ }^{6}$ La fuente principal es el libro Vı de las Vidas de los filósofos más ilustres, de Diógenes Laercio. El lector también puede hallar una exhaustiva antología del rico anecdotario cínico en la antología de testimonios Los filósofos cínicos y la literatura moral serioburlesca, de José A. Martín García, donde también pueden leerse las famosas Epístolas pseudodiogénicas (2008: I, 391-429).

${ }^{7}$ Es fundacional dentro del discurso humanista el De mi ignorancia y de la de muchos otros de Petrarca.

${ }^{8}$ No es extraño que el único libro del Antiguo testamento del que se ocupó Erasmo intensivamente fuese el Eclesiastés, del que hizo una paráfrasis en 1534
} 
Como decíamos más arriba, esta omnipresencia de la autoderrisión nos lleva a sospechar que nos hallamos ante un motivo fundamental de la cultura occidental. Un lugar por el que iniciar el descenso hacia esta especie de placa tectónica cultural se halla en Le rire, de Henri Bergson, donde se afirma que "en la risa siempre hallamos la intención inconfesada de humillar y, por lo tanto, de corregir a nuestro prójimo" (2008, cit. en Johnson, 2012: 13) ${ }^{9}$. De algún modo, reírse de la humanidad a través de uno mismo tendría como objetivo ejercer una especie de humillación pedagógica que supondría un cierto acendramiento filosófico o, incluso, religioso. Ciertamente, en su origen, la autoderrisión o autodeprecación estuvo estrechamente conectada con la experiencia religiosa. Recordemos, para empezar, que, según el $D R A E$, la primera acepción del verbo "humillar", esto es, 'inclinar o doblar una parte del cuerpo, como la cabeza o la rodilla, especialmente en señal de sumisión y acatamiento', designa la genuflexión que suele realizarse antes de entrar en un templo religioso. Por su parte, la famosa inscripción que se hallaba grabada en el frontón del templo de Apolo, en Delfos, y que rezaba "conócete a ti mismo", no debería ser interpretada, como tantas veces se ha hecho, en términos psicológicos, sino, antes bien, en términos religiosos, esto es, como una exhortación a tomar conciencia de la insignificancia del hombre frente al dios que se está a punto de adorar.

Como era de esperar, en el seno del mundo clásico, la autoderrisión trascenderá la esfera meramente religiosa. La autohumillación o genuflexión espiritual será vista en el mundo grecolatino como vía y meta de sabiduría, y es una constante no solo de sus más importantes expresiones filosóficas (socratismo, escepticismo, cinismo, epicureísmo), sino también literarias (Homero, Sócrates, Eurípides, Pirrón, Lucrecio, Luciano). Podríamos llegar a afirmar que una de las características fundamentales de la voz de los clásicos es precisamente esta entonación autoderrisoria, que no sería un simple rasgo formal, ni siquiera tonal,

\footnotetext{
${ }^{9}$ La bibliografía acerca de la risa es inabarcable. Además del libro de Bergson, que aquí utilizamos más como punto de partida que como marco teórico, pueden destacarse los Escritos filosóficos de Mosses Mendelsohn (1729-1786), donde se afirma que la risa es el contraste entre la perfección y la imperfección; la Crítica del juicio (1790) de Kant, donde lo cómico es dotado de un estatuto epistemológico, por ofrecer una percepción distinta, pero no totalmente falsa, de la que nos ofrece la razón; la Estética de Jean Paul Richter, que trató de aumentar la concepción kantiana del humor, explorando los aspectos más subjetivos de la comicidad, que no sería solo el resultado de una situación o característica objetiva, sino también de una actitud o forma subjetiva de mirar el mundo; las Lecciones sobre estética de Hegel, para el que lo cómico resultaba de la contradicción entre la "pesadez" del mundo real y la "levedad" del mundo del espíritu humano; la Postdata acientífica a modo de conclusión (1842), publicada por Kierkegaard bajo el seudónimo de Johannes Climacus, donde afirma que la raíz de lo cómico y de lo trágico es la contradicción entre lo infinito-eterno y lo finito-provisorio, para afirmar, luego, que lo cómico es la antesala de la fe; El chiste y su relación con el inconsciente de Freud, quien vio en la risa un mecanismo de liberación del inconsciente reprimido; "Sobre la risa", incluido en Subjetividad (1940), de Joachim Ritter, donde se niega la idea de que lo cómico se basa fundamentalmente en la incongruencia y se lo entronca con la idea de juego; o Die Komoedie, de Greiner (1992: 25-26), donde se nos informa que el término "comedia" procede de "komodia", que significa 'el canto del komos', que era el grito de la multitud que participaba en los ritos dionisíacos. Vale también la pena destacar obras como Risa redentora (1997, traducido en 1999), de Peter Berger, quien tras una cartografía excelente de los diferentes tipos de la risa se centra en la relación de ésta con la religión y la filosofía; o De Job a Woody Allen: el humor judío en la literatura (2000), de Stora-Sandor, que se centra en las particularidades del humor judío a lo largo de la historia.
} 
sino que estaría conectada con una concepción religiosa de la sabiduría consistente en la alegre aceptación de las limitaciones de la condición humana.

Más aún, la autoderrisión llegará a constituirse en uno de esos "ejercicios filosóficos" o "espirituales" con los que las diversas escuelas filosóficas buscaban liberar al hombre de las "pasiones tristes", por utilizar el término spinoziano, que le impiden el acceso a la felicidad. Recordemos, con Pierre Hadot, que, según la filosofía antigua, en general, la principal causa de sufrimiento del hombre proviene de las pasiones, contra las que cada escuela filosófica, en particular, propone un método terapéutico constituido por unos ejercicios espirituales que no solo buscan liberarnos de las pasiones específicas que nos torturan, sino que también persiguen una transformación global del ser $(2006: 26)^{10}$. El humor, particularmente la autoderrisión, tendrá una función fundamental en este proyecto terapéutico y psicagógico ${ }^{11}$. Los epicúreos, por ejemplo, utilizarían la autoderrisión para liberar al hombre de sus miedos y ansiedades, como prueban algunas máximas de Epicuro y numerosos fragmentos del De rerum natura, de Lucrecio, donde se insiste en la insignificancia y ridiculez de los hombres, con el objetivo de restar dramatismo a la muerte y a todas esas fantasías, religiosas o no, que le impiden vivir con alegría. Por su parte, los escépticos utilizarán la autoderrisión para aligerar al hombre de sus excesivas pretensiones de conocimiento, que tienden a provocar ansiedad, en el nivel individual, y fanatismo, en el nivel colectivo. Ese es, precisamente, el objetivo de Sexto Empírico, Luciano, Montaigne, Cervantes o Borges cuando se burlan (estilística, argumental o ficcionalmente) de sus propias insuficiencias cognitivas. También, como vimos, las anécdotas protagonizadas por los filósofos cínicos, particularmente por Antístenes, Diógenes de Sínope o Crates, buscaban destruir la idea excesivamente elevada que el hombre tiene de sí mismo en tanto ser civilizado, con el objetivo de depurarlo y ponerlo en la vía de una vida más libre y natural. Incluso el estoicismo, mucho más serio y pomposo, utilizó la autoderrisión para aleccionar al hombre acerca de su auténtico tamaño y función en el seno del cosmos, con el objetivo último de librarlo de su tendencia a fatigarse tras lo imposible y frustrarse ante lo ineluctable. ¿No está ridiculizándose a sí mismo, y a través de sí mismo al ser humano, Marco Aurelio cuando afirma, en sus Meditaciones, que "la relación sexual es una fricción del intestino y eyaculación de un moquillo acompañada de cierta convulsión" (VI, xiii, 115)?

No solo el mundo grecolatino, sino también el mundo cristiano le otorgaría un papel fundamental a la autoderrisión, si bien es cierto que su función no será tanto psicagógica como teológica y que durante la época medieval fue

\footnotetext{
10 Según estudió brillantemente el historiador de la filosofía Pierre Hadot, si bien el término exercitia spiritualia suele estar asociado con la tradición cristiana, lo cierto es que dicho término no solo "está documentado desde mucho antes de Ignacio de Loyola", en el antiguo cristianismo grecolatino, sino también en la askesis de las escuelas helenísticas (2006: 24).

${ }^{11}$ Véase al respecto El concepto de la ironía en Sócrates, donde Kierkegaard afirma que Sócrates estaba más cercano de Antístenes o de Diógenes (a quien significativamente Platón llamó "Sócrates enloquecido") que de ningún otro filósofo, y que la ironía o autoironía es una especie de "ejercicio espiritual", semejante a los que él mismo realizaba con su padre, consistente en humillar al hombre, haciéndolo de este modo más receptivo para la fe.
} 
sustituida por un tipo de autohumillación más dolorista, culpabilista y aterradora. Recordemos, con el sociólogo Peter Berger, que uno de los conceptos fundamentales del cristianismo es la idea de que Dios se humilló al descender de la infinita majestad divina para adoptar la forma del ser humano más despreciado y ridiculizado (2006: 303). Tanto es así que el misterio esencial de la redención parece ser la irónica coincidencia entre el Cristo humillado, y burlado, de la Pasión y el Christus Victor de la mañana de Pascua. Desde entonces, todo hombre considerado necio, loco o ridículo por seguir a Cristo simboliza la kenosis, esto es el "vaciamiento" o "humillación" de Dios, que redime al mundo. No es extraño, pues, que todo el cristianismo se estructurase en torno a un programa kenótico, concebido como un ejercicio permanente de humillación que no solo aceptaba una entonación ascética y rigorista sino también autoirónica y festiva (Berger 2006: 303). Ciertamente, dicho programa se halla presente, de diversas maneras, en las prácticas autodeprecativas de los monjes del desierto en Egipto, en las extravagancias de los predicadores callejeros del cristianismo ortodoxo oriental, en las "locuras" de San Francisco de Asís, en la "santa ignorancia" de Nicolás de Cusa, en el Elogio de la locura de Erasmo, en el exhibicionismo de Montaigne, en la ironía ascética de Kierkegaard y El idiota de Dostoievski, o en el escepticismo festivo de Chesterton.

Vale la pena insistir en que el programa kenótico cristiano tiene muchas declinaciones. Así, en la Europa del Renacimiento, de la mano de Lorenzo Valla, Erasmo, Rabelais y Montaigne, la autodeprecación kenótica confluirá con el epicureísmo y el escepticismo, y más que humillar al hombre frente a la divinidad, al modo del libro de Job, buscará liberar a los hombres de los miedos y ansiedades religiosos, con el objetivo de reestablecer una vivencia más humana y tranquila del mundo y de la religión. Por su parte, el romanticismo, con Kierkegaard a la cabeza, presentará la ironía como la fase existencial o camino espiritual que precede a la fe, puesto que nos muestra la situación irónica, incongruente del hombre entre, como decía Pascal, el cero y el infinito (Berger 2006: 303).

Señalemos brevemente que, durante la primera crisis de la modernidad, a finales del siglo $\mathrm{XIX}$ y principios del $\mathrm{xX}$, numerosos autores, como Friedrich Nietzsche, Fritz Mauthner, Edmund Husserl, William James, Martin Heidegger o José Ortega y Gasset, que no solo veían en la euforia cientificista de la "modernidad" un pecado de hybris, sino también un camino equivocado, iniciaron una tarea de humillación de las excesivas pretensiones modernas. Desde diferentes perspectivas, Chesterton, Borges o Machado de Assis, tan influyentes todos en la obra de Fernando Iwasaki, trabajaron consciente o inconscientemente en esa dirección. La segunda crisis de la modernidad, que hemos dado en llamar posmodernidad, con Gadamer, a la cabeza, y luego el neonietzscheanismo de Foucault, Lyotard o Vattimo, supondrá el reinicio del programa kenótico iniciado por Nietzsche tras su congelación durante las dos guerras mundiales y las dos primeras décadas de la posguerra ${ }^{12}$.

\footnotetext{
12 Véase al respecto el excelente ensayo Cosmópolis. El trasfondo de la modernidad (2001), del historiador de la ciencia Stephen Toulmin.
} 


\section{LA AUTOdERRISIÓN EN LA OBRA DE FERNANDO IWASAKI}

En el prólogo de la antología de artículos periodísticos titulado Una declaración de humor, Fernando Iwasaki afirma que "reírnos de nosotros mismos" es una "fase superior del humorismo" (2012b: 9). Unas líneas más abajo, el autor se suma a una larga tradición de caídas epifánicas, que incluye a Tales de Mileto cayéndose en un pozo, a Diógenes de Sínope chocando contra los atenienses que salen del teatro y a San Pablo cayéndose del caballo, al utilizar la imagen del "patinazo" para afirmar que la autoderrisión es un elemento necesario para que el humor sea auténtico:

... la epifanía humorística solo nos traspasa si aprendemos a reírnos después de hacer un papelón o cuando nos viene la risa floja después de pegar un patinazo. Tal es la diferencia que existe entre caerse y "tirarse al suelo", porque si Saulo se hubiera "tirado al suelo", jamás se habría convertido en san Pablo. (Iwasaki 2012b: 9)

Asimismo, en su libro de cuentos España, aparta de mí estos premios, Iwasaki describirá a su lector ideal, lo que no deja de ser una de las formas del arte poética, como aquel que sabe reírse de sí mismo: "hay dos Españas y solo es posible escribir para una de las dos. Mi elección es clara y rotunda: siempre escribo para la España que sabe reírse de sí misma (2009b: 14).

Parece lícito, partiendo de este tipo de afirmaciones, atribuir a Fernando Iwasaki una distinción entre un humor auténtico y un humor inauténtico. Pero, aunque nuestro autor llegue a afirmar que "la finalidad del humorismo no es hacer reír sino hacer pensar" (2012b: 9), sería un error pensar que, para él, la trascendencia cognoscitiva es la única finalidad del humor auténtico. Recordemos, por ejemplo, cómo, en la dedicatoria de Una declaración de humor, se habla de la necesidad de curarnos mediante el humor de "la bilis y la solemnidad" (2012b: 7), y cómo, en rePublicanos, se reivindica el humor como arma de emancipación política ${ }^{13}$. Podemos distinguir, pues, con Iwasaki, al menos tres virtudes del humor, en general, y de la autoderrisión, en particular: cognoscitivas, existenciales y políticas.

En lo que respecta a las virtudes cognoscitivas de la autoderrisión, destaquemos el efecto desalienante que tiene la autoironía en relación con las ficciones, idealizaciones, deformaciones o manipulaciones que obstaculizan el autoconocimiento. Los autores, en general, y Fernando Iwasaki, en particular, suelen utilizar dos grandes tipos de estrategias autodeprecativas. La primera se centraría en los aspectos fisiológicos que caracterizan la vida del ser humano, mientras que la segunda se ocuparía más bien de los aspectos existenciales o morales.

Uno de los motivos habituales de lo que podemos llamar "autoderrisión fisiológica" es el del fracaso amoroso o sexual, un tema esencial en la obra de

13 "¿Por qué no hemos querido reírnos más y mejor de nuestros caudillos? Con las honrosas excepciones de Serna e Ibargüengoitia, casi ningún escritor latinoamericano ha perseverado en la imagen esperpéntica del dictador inaugurada por Valle-Inclán" (Iwasaki 2008: 99). 
Fernando Iwasaki, quien llegará a dedicar toda una obra, titulada el Libro del mal amor (2001), a narrar "diez de mis fracasos amorosos más espectaculares" (2005a: 17). También los cuentos que conforman Helarte de amar (2012a) están poblados por personajes desorientados, desbordados, desconcertados o desubicados en sus experiencias sexuales. Así, el protagonista del relato que da título a la colección se encuentra embarcado permanentemente en situaciones ridículas debido a que su pareja solo alcanza la excitación a temperaturas extremadamente bajas (2012a: 20-46); el protagonista del relato titulado "En el batimóvil, con Miss Graciela" (2012a: 14-22) es un niño cuya visión del sexo, además de cándida, está totalmente distorsionada por el imaginario de la cultura de masas infantil; y, en "Las memorias de Madame Quiñónez" (2012a: 23-27), las enrevesadas fantasías sexuales de los clientes de un prostíbulo nos los revelan como seres ridículos y precarios.

También en el capítulo "Melodías de Mocedades", incluido en El descubrimiento de España, se narran fracasos amorosos, incidiendo en sus aspectos más ridículos (1996: 64). Finalmente, en prácticamente todos los artículos periodísticos recogidos en Una declaración de humor, lo que podemos Ilamar "el yo periodístico" se presenta como un coleccionista de fracasos amorosos. Así, en "Ligar en abstracto", este afirma haber intentado usar el arte para seducir, "pero nunca me comí ni medio rosco" (2012b: 14); en "El amante pasivo", explica que su psicoanalista le ha recomendado "que aproveche los estímulos del entorno para sublimar la experiencia sexual" y se convierta "en un amante pasivo" (2012b: 16); y en "Ser mono en Jerez" afirma que tras estudiar los hábitos sexuales de los animales, con el objetivo de mejorar sus dotes de seducción, "yo era capaz de enamorar a una nutria, un caimán o una cigüeña, pero del todo inútil con el personal de mi especie" (2012b: 107). Cabe insistir en que la autoironía de tema sexual y amoroso que caracteriza todos los relatos de este libro es, por metonimia, símbolo del carácter trágico de la existencia humana en su conjunto, por la sencilla razón de que esa insuficiencia o impotencia fisiológica o cognoscitiva en lo que respecta al mundo de la sexualidad es una experiencia universal. Del mismo modo que en las novelas de dictador suele producirse una inconsistencia irónica entre el poder absoluto del tirano y su tópica impotencia sexual, en la narración de estos fracasos amorosos, la sexualidad es símbolo de la incongruencia entre la pequeñez, impotencia o ignorancia de los hombres y la infinitud, omnipotencia e incognoscibilidad del universo ${ }^{14}$.

Pero la sexualidad no es el único proceso fisiológico que nos presenta al hombre como un ser ridículo ( $y$, no lo olvidemos, liberado de miedos, angustias

\footnotetext{
${ }^{14}$ En su brillante ensayo Risa redentora, Peter Berger pone como ejemplo de la "discrepancia fundamental entre el ser humano y la enormidad elefantiásica del universo" el siguiente chiste: Un ratón se topa con una elefante y le dice: -Oh, señorita, siempre he deseado hacer el amor con una elefanta. La elefanta se ríe pero le dice: -¿Por qué no? Adelante, ratoncito. La elefanta se tumba debajo de un cocotero y se acomoda como buenamente puede para que el ratón pueda acoplarse. Al cabo de un rato la elefanta se duerme, pero, entonces, una ráfaga de viento sacude los árboles y un coco se desprende y cae sobre la cabeza de la elefanta. Esta se despierta y exclama: -¡Ay! Y el ratón le responde solícito: -¡Oh, cuánto lo siento! No quería hacerle daño (2006: 64).
} 
y expectativas excesivas), sino también todos aquellos que están relacionados con las funciones escatológicas. El estornudo, el eructo, la flatulencia, el ruido de tripas o el sudor no solo despiertan hilaridad por su carácter inesperado, sino también por contravenir la concepción excesivamente espiritual y sublime que el ser humano tiene de sí mismo. Ciertamente, a diferencia de los Ensayos de Montaigne, en la obra de Iwasaki no hallamos una autoderrisión de temática explícitamente escatológica, si bien en una novela como Neguijón se narra la historia de un sacamuelas obsesionado por hallar el fantástico gusano que en el siglo Xvı se creía que ocasionaba las caries, y que, según se dice, "anida entre la roña y las grietas de los dientes" (2005b: 79). A lo largo de toda la novela son constantes las referencias a las funciones fisiológicas y a las enfermedades, que no son presentadas como un elemento accidental, sino, antes bien, como una constante necesaria y específica de toda existencia: "En realidad, a todos les dolía algo aquella mañana: uñeros, lobanillos, sietecueros, hernias, migrañas, cólicos, panadizos, tumores, ciáticas y almorranas" (2005b: 15). Y entre todas estas enfermedades o taras, se halla la caries, símbolo del carácter a la vez doloroso e inocuo de la existencia humana, según apuntan diversos pasajes de la novela: "engendradas en los fangos de la boca y en los meollos de las muelas, cuyos mordiscos traspasaban de dolor y cuya podredumbre era el principio de la corrupción de nuestros cuerpos (2005b: 134) ${ }^{15}$.

Junto a la sexualidad, las necesidades perentorias y las enfermedades como motivos autoderrisorios, nos encontramos también con la muerte. Para empezar, tal y como subraya ese irónico azar etimológico que nos ha llevado a denominar como "escatológico" todo lo que a ella se refiere, no solo el ser que agoniza, sino también el cadáver mismo protagonizan todo tipo de procesos fisiológicos (defecaciones, orines, gases, estertores, gemidos, sudores), que a pesar del contexto de dolor y de tristeza pueden llegar a despertar hilaridad. Así, en Inquisiciones peruanas (1994), entremezcladas con la regocijada descripción de las heterodoxias sexuales y religiosas de ciertos personajes históricos de la América colonial, se realizan numerosas alusiones a las funciones escatológicas, tan presentes en salas de tortura, hogueras y cadalsos $^{16}$.

Más allá de su carácter doblemente escatológico, la muerte en sí misma tiene una fuerte vis cómica. Una caída fatal, un cadáver en una postura imposible, un suicidio frustrado, una imprudencia estúpida y fatal o unas últimas palabras cuyo destinatario no llegó a oír debido a un despiste o a un ruido casual son ciertamente situaciones que pueden hacer gracia y, lo que es más importante, ponen al hombre en su sitio, puesto que le recuerdan su carácter indefenso, ignaro y ridículo. Esta es, precisamente, la sensación que experimenta el lector de la colección de microficciones titulada Ajuar funerario (2009a), donde la muerte

\footnotetext{
15 Véase también los siguientes ejemplos: "naufragando su entendimiento y agusanándose la almendra del cerebro" (Iwasaki 2005b: 138); "antes de que su alma se agusanara como una muela" (Iwasaki 2005b:149).

${ }^{16}$ Esa es, claramente, la intención de la escritora Rosa Sala Rose cuando nos informa que, durante la grabación del Triunfo de la voluntad, de Leni Riefenstahl, hubo numerosos problemas logísticos para que los numerosos figurantes pudiesen satisfacer sus necesidades fisiológicas.
} 
es narrada siempre desde un enfoque que nunca deja de recordarnos, utilizando las palabras de Desmond Morris (2003), que somos un "mono desnudo".

En lo que respecta a lo que podemos llamar "autoderrisión moral o existencial", nos encontramos, con la burla del carácter existencialmente ridículo del ser humano, cuya infantil presunción contrasta con su inconsistencia, su mediocridad, su soledad o su brevedad, y, particularmente, con la burla de la ignorancia que lo caracteriza y que no solo lo lleva a desconocer la infinita complejidad del universo, seguramente para olvidar que este lo aniquila, sino también su propia identidad, ya sea individual o colectiva. Así, en la estela del escepticismo borgeano, son constantes las protestaciones de ignorancia del autor: "mi ignorancia" (1996: 176), "mi vasta ignorancia" (2011: 17), etc.

También es habitual en la obra de Fernando Iwasaki que el autor se presente a sí mismo, y por extensión a toda la humanidad, como una secuela de la niñez. La candidez, incomprensión y desorientación que caracteriza a los niños y que nos los hace al mismo tiempo ridículos y entrañables perdura en el ser adulto, que frente a la inmensidad del cosmos nunca dejará de ser un niño. A eso mismo apuntan muchos de los chistes que Kierkegaard recogió, bajo el nombre de Johannes Climacus, en su Postdata acientífica a modo de conclusión. Baste recordar aquel que presenta a un niño de cuatro años diciéndole a un niño de tres: "tranquilo, corderito". Esa especie de mise en abîme que tras hacernos reír o sonreír de la candidez de un niño nos hace sentir que nosotros somos igualmente cándidos respecto de otras realidades superiores es una constante en la obra de Iwasaki. Recordemos, a modo de ejemplo, el capítulo "Mi voz igual que un niño" de El descubrimiento de España (1996: 11-65), el ensayo "El texto como pretexto", incluido en Mi poncho es un kimono flamenco (2005a: 13-19), el relato "En el batimóvil, con Miss Graciela", recogido en Helarte de amar (2012a: 14-22), así como muchas de las microficciones incluidas en Ajuar funerario (2009a).

Otra de las estrategias derrisorias más habituales consiste en burlarse de las capacidades descriptivas, racionales e, incluso, pragmáticas del lenguaje. El carácter autoderrisorio de este tipo de burlas es paradójico, por autorreferencial, ya que se ríe tanto del lenguaje humano, en general, como de la burla que se está produciendo en ese mismo momento. En la obra de Fernando Iwasaki la autoderrisión lingüística es omnipresente. Baste, a modo de ejemplo, un título como Helarte de amar (2012a), que remite a la obra homófona de Ovidio; España, aparta de mí estos premios (2009b), que parodia una obra poética de César Vallejo; o infinitos juegos de palabras como utilizar el término "ciencia-fricción" para referirse al carácter fantasioso de las historias eróticas incluidas en Helarte de amar (2012a: 12); decir que las funerarias del Perú son "más pomposas que fúnebres" (2009a: 11); hacer que un personaje afirme que van a envenenar a un japonés con un daiquiri (2009b: 51); decir que unas monjas "ya no eran madres", precisamente porque habían tenido hijos (1996: 15); hablar de "Fantasías textuales" (2012a: 83); o, finalmente, bautizar a algunos de los personajes de Helarte de amar con nombres como "Tecacho Arakama" o "Boris Fornikov" (2012a: 69).

Los constantes juegos de palabras tienen un efecto demoledor sobre la confianza que los hombres suelen tener en las capacidades cognoscitivas del 
lenguaje. Cada juego de palabras nos recuerda de un modo festivo el carácter vago, ambiguo, confundente, caricaturesco o violentador del lenguaje. Ciertamente, el juego de palabras tiene un escaso predicamento en la literatura española contemporánea. Si de alguna fuente bebe Iwasaki es, a través de Guillermo Cabrera Infante, de la literatura inglesa, que tiene mucha más estima por el juego de palabras o spun. Iwasaki escribe, por utilizar el neologismo del autor de Tres tristes tigres, en spunish, esto es, en un español plagado de juegos de palabras, hecho que le ha costado caro en una tradición dominada por los agelastos, que es el término griego que rescató Rabelais para referirse a aquellos que no sabían reír, por tomárselo todo, incluso a sí mismos, muy en serio. Recordemos que dicha seriedad no solo contravenía las creencias epicúreas de Rabelais, sino también el mismísimo mensaje cristiano, por lo menos tal y como lo entendía el erasmismo, al que este se adscribía.

Cabe añadir que la autoderrisión lingüística suele ir asociada a una sensibilidad de corte escéptico, que, al mostrarse consciente de las limitaciones del lenguaje, adopta una posición más tolerante y dialogadora. Esa fue, precisamente, la apuesta de los erasmistas y su consuetudo, de Montaigne y su "que sais-je?", de Cervantes y sus vacilaciones lingüísticas (recuérdese el famoso episodio de las "truchuelas"), de Shakespeare y sus "palabras, palabras, palabras" o de Borges y sus críticas mauthnerianas del lenguaje. Pero, como dice Iwasaki en rePublicanos, parodiando el inicio de Conversación en la Catedral, de Vargas Llosa, el momento en que España "se jodió" fue cuando eliminó de su seno la tradición erasmista y, con ella, su escepticismo lingüístico (2008: 25). En este sentido, la autoderrisión lingüística, tan sistemáticamente practicada por Iwasaki, entronca con un proyecto de rescate de la voz humanística que la Contrarreforma, de un lado, y la modernidad cartesiana, del otro, marginaron ${ }^{17}$.

Añadamos que la autoderrisión lingüística adopta, en Fernando Iwasaki, otras formas además del juego de palabras. Nos encontramos, por ejemplo, con numerosas expresiones que buscan rebajar, cuando no contradecir, las afirmaciones que se están realizando ("quizás", "es posible que me equivoque", "puede ser", "también es cierto que", "no es improbable que"), así como con reflexiones humorísticas acerca del carácter imperfecto o, incluso, superfluo del lenguaje:

Palabras como "glúteo", "picaporte", "intravenosa" o "exquisito" estaban ausentes de nuestro acervo infantil, mas no las necesitábamos porque bastaba con referirse a la "cosa" o al "esto" o con decir "me duele" o "me gusta". Del mismo modo, cada vez que hacemos el amor prescindimos de los conceptos anatómicos y las complicadas definiciones latinas, ya que esas "cosas" y aquellos "estos" bien pueden llamarse "picaporte" o "intravenosa", y sigue siendo suficiente "me duele" o "me gusta". (Iwasaki 2005: 13)

Lo que hemos dado en Ilamar "autoderrisión existencial o moral" también tiene por objeto la propia identidad, ya sea colectiva o individual. Como vimos más arriba, este tipo de autoderrisión identitaria es, para Fernando Iwasaki, un

17 Véase al respecto Toulmin (2001 y 2003) y Castany Prado (2012c). 
atributo fundamental de su lector ideal. No es extraño, pues, que la burla de sus propias adscripciones identitarias sea una constante en toda su obra. Para empezar, en la tradición de Lima la horrible, de Salazar Bondy, Iwasaki se ríe de su propia ciudad de origen en el "Exordio" de Inquisiciones peruanas. Sus burlas tienen por objeto desmontar la versión oficial de lo que es Lima: "limpia ciudad perfumada de magnolias", habitada por una "población entregada a los rezos" (2007: 17). Es interesante que el autor diga que se propone "redimir" (19), con su libro, la ciudad de Lima, ya que, de este modo, este tipo de autoderrisión identitaria se nos muestra como una herramienta de autoconocimiento y de crítica. La risa revela la realidad limeña, promiscua, mestiza, desordenada y sucia, por la sencilla razón de estar viva, redimiéndola de la frialdad y esterilidad del puritanismo, que espera de ella que sea "una ciudad pacata y pudibunda [...] cucufata y santurrona" (19).

Iwasaki no solo se reirá de su ciudad de origen, sino también de las diferentes culturas y nacionalidades de las que participa. Así, en rePublicanos, en la línea de la literatura antipatriótica de Gombrowicz, Musil, Bernhard, Copi, Fogwill o Castellanos Moya $^{18}$, nuestro autor no tiene problema en afirmar que España y Latinoamérica "compartimos las mismas taras y miserias" (2008: 27); entre otras, padecer el "narcisismo botarate de las sociedades cerradas" (30), haber protagonizado "Una modernidad a la antigua" (21-30), haber vagado "A oscuras en el siglo de las luces" (31-43) o haber sufrido una verdadera furia constitucional ("en menos de doscientos años España y los países hispanoamericanos acumulamos un total de 403 textos constitucionales", 72).

Por si esto no fuese suficiente, nuestro autor se reirá también de la identidad humana. Nuevamente, su objetivo es redimirla de la alta concepción que esta tiene de sí misma, para reconciliarla con su identidad verdadera, menos sublime, ciertamente, pero más viva y alegre. Desde este punto de vista, la historia de la humanidad no es esa progresiva elevación hacia la perfección absoluta, sino, antes bien, un hormigueo caótico y ridículo del que puede nutrirse la literatura: "si fuera cierto -como creía Marx- que la historia se repite la primera vez como tragedia y la segunda como farsa, a partir de la cuarta o quinta repetición tal vez sólo nos quede la literatura (2008: 19).

Pero Iwasaki no solo se ríe de Lima, Sevilla, Perú, España o la humanidad, en particular, sino, lo que es más importante todavía, del puritanismo identitario, en general. Así, frente al furor identitario de Antonio Cornejo Polar, que considera que "la revelación y crítica de la realidad del país ha sido y sigue siendo una tenaz obsesión de la narrativa peruana" (1997: 27, cit. en Iwasaki 2008: 51), nuestro autor considera que "la revelación y crítica de la realidad del país no es precisamente una obsesión de los narradores, sino más bien de los críticos, filólogos, periodistas y estudiosos varios de la realidad peruana" (51). Ciertamente, el humor es un modo de rebajar este dogmatismo identitario, causa de ansiedades individuales y fanatismos colectivos. Así, en el capítulo titulado "El huevo y la gaIlina o la identidad y la independencia" (2008: 133-147), recurrirá a las paradojas

18 Sobre el concepto de "literatura antipatriótica", véase Castany Prado (2012a). 
para reducir al absurdo las pretensiones identitarias españolas y latinoamericanas: "¿No es curioso que en América Latina nos hayamos independizado por no saber quiénes éramos, mientras que en España hay comunidades que se quieren independizar precisamente porque ya saben quiénes son?" (2008: 142). El mismo Iwasaki notará la relación de este tipo de argumentos con los paralogismos de la razón mediante los cuales Kant pretendía, en su Crítica de la razón pura, reducir al absurdo las pretensiones dogmáticas de la metafísica precrítica: "La identidad nacional es un recurso muy socorrido que lo mismo sirve para negar una cosa y la contraria, pero que en cualquier caso siempre será una abstracción" (2008: 142). Y del mismo modo que Kant afirma haber despertado, gracias a Hume, de su "sueño dogmático", Iwasaki considera haber evolucionado del dogmatismo identitario de su primer ensayo, titulado Nación Peruana: entelequia o utopía (1988), que más tarde consideraría "intelectualmente ingenuo y de un cándido optimismo, pues tener o no tener identidad nacional no nos hace peores ni mejores a los individuos" (2008: 143), al "eclecticismo" identitario de Mi poncho es un kimono flamenco. Necesariamente, este eclecticismo va a tener un componente humorístico, ya que convoca uno de los elementos fundamentales del humor: la incongruencia. Ya sea entre los elementos que componen una identidad, ya sea entre la realidad individual, irreductible, inconmensurable, y las identidades en las que se las quiere subsumir. Así, en el texto introductorio de Mi poncho es un kimono flamenco, Iwasaki aspira a "redimir" su propia identidad del puritanismo identitario con la misma estrategia que usó en Inquisiciones peruanas, esto es, mostrando la promiscuidad, mestizaje y desorden que se dan cita en su propia persona: "En más de una ocasión he tenido que hablar acerca de literatura e identidad, lo cual parece un despropósito cuando uno vive en España, tiene apellido japonés y ha nacido en el Perú. Por eso siempre respondo que mi poncho es un kimono flamenco" (2005a: 11). Unas páginas más adelante, en el breve ensayo titulado "La visa múltiple como identidad en la narrativa peruana contemporánea", Iwasaki volverá a bromear acerca de su propia desubicación identitaria: "aunque les dijera que en mis narraciones refulge nevada y precolombina la telúrica identidad peruana, teniendo un apellido japonés y viviendo en Sevilla, no espero que me crean en Londres" (2005a: 43). Poco después, Iwasaki encarnará este argumento en una anécdota de corte humorístico que lo sitúa en una situación ridículamente kafkiana, pues es un policía de aduanas en el aeropuerto de Kennedy, en Nueva York, quien le pregunta: "¿Por qué usted viaja con pasaporte español si tiene apellido japonés y ha nacido en Perú?" (2005a: 45).

Cabe señalar que ya Diógenes de Sínope, una de las principales figuras de la autoderrisión, consideró el destierro, la extranjería e, incluso, la barbarie como una postura filosófico-literaria privilegiada: "Diógenes fue desterrado: “¡No estuvo tan mal!", porque comenzó a filosofar después del destierro" (Plutarco, Sobre la paz del alma, 6, § 467 c, t. VII, 124) 19. También Borges llegará a afirmar que la lejanía -física, cultural o identitaria, no importa- le permitía liberarse de los

\footnotetext{
${ }^{19}$ Plutarco vuelve a hacer referencia a esta idea en Cómo sacar provecho de los enemigos: "Algunos hicieron, como Diógenes y Crates, del destierro de la patria y de la pérdida de riquezas viático para el ocio y para la filosofía" $(2, \S 87 a$, t. I, 309).
} 
nacionalismos -"Europa es Europa toda entera, Europa es una" (2003: 371)-, así como de ese otro nacionalismo que es el eurocentrismo -"precisamente debido a nuestra distancia de Europa también tenemos la libertad cultural o imaginativa para mirar, más allá de Europa, hacia Asia y otras culturas" (371). Al fin y al cabo, Borges también había utilizado las paradojas para evidenciar el carácter irreductiblemente plural y entremezclado de la realidad frente al puritanismo identitario: "Eden Phillpotts 'el más inglés de los escritores ingleses' es de evidente origen hebreo y nació en la India" (1999: Iv, 273); "los japoneses ejercen el Occidente mejor que nosotros" (2003: 359).

No es extraño, pues, que la desubicación identitaria sea uno de los elementos fundamentales de toda la obra de Fernando Iwasaki. Recordemos, por ejemplo, que los relatos que incluye España, aparta de mí estos premios no dejan de ser exorcismos autobiográficos, al estilo de los Ensayos de Montaigne o de los Ejercicios autobiográficos de Santayana. Así, todos esos nacionalistas españoles, andaluces, catalanes o vascos ridículamente obcecados en su unicidad incomparable ${ }^{20}$, son cifra de las experiencias del propio autor, cuya identidad múltiple debió excitar numerosos recelos, preguntas, bromas e impertinencias por parte de los puritanos de la identidad ${ }^{21}$. Dichas experiencias también aparecen cifradas en la caricaturesca fotografía que aparece en la solapa de España, aparta de mí estos premios, donde aparece sentado en la posición del loto con una banda japonesa atada a la frente.

No debemos, sin embargo, sobredimensionar la importancia de los aspectos nacionales, culturales o lingüísticos de la identidad de Fernando Iwasaki, en particular, ni de ninguna otra identidad, en general. Lo cierto es que, para un escritor, el rasgo más importante de su identidad es el hecho mismo de dedicarse a la escritura. Ese es, precisamente, otro de los motivos fundamentales de un libro como España, aparta de mí estos premios, donde Iwasaki exhibe, seguramente también a modo de exorcismo, su capacidad para reírse de su propio destino como escritor. Como era de esperar, dichos relatos no presentan al escritor como un pararrayos celeste, un vocero del pueblo o un poeta maldito, sino más bien como un ser que prostituye su pluma con la esperanza de ganar algún premio literario menor que le permita "comer caliente, llegar a fin de mes e incluso comprarse un ordenador nuevo" (Iwasaki 2009: 13). Esta autonegación en tanto que ser especial es una constante en toda su obra. Así, en el ensayo titulado "El texto como pretexto", incluido en Mi poncho es un kimono flamenco,

\footnotetext{
20 Recordemos el antológico inicio de la primera "Acta del jurado" que incluye dicho libro: "Reunidos en la localidad de Benaoján, en el marco incomparable de la IV Feria de la Chacina, los miembros del jurado del Iv Certamen de Relatos Espeleológicos 'Cueva de La Pileta'..." (Iwasaki 2009b: 33).

21 Lila Medjahed estudia la auto-deprecación como "una forma de apaciguar un malestar identitario" (2005: 30) en las novelas del escritor francés de origen argelino Azouz Begag. Por su parte, Cerf (1994) estudia la importancia de la autoderrisión en una región como Alsacia, en la que los cambios de nacionalidad, lengua y cultura dominantes han sido frecuentes y Nezri-Dufour (2000) estudia la autoderrisión, centrándose en la novela Si no ahora, ¿cuándo? de Primo Levi, como una técnica de supervivencia basada en el distanciamiento y en el consuelo que produce la sensación de que uno controla aquellas situaciones de las que puede reírse.
} 
Iwasaki afirmará que, a pesar de ser "un lugar común remontarse a la infancia para explicar cómo surgió en uno mismo la vocación de escribir", él va a incurrir en ello "precisamente porque soy una persona común y corriente" (Iwasaki 2005a: 13). Asimismo, en el "Decálogo del concursante consuetudinario (y probablemente ultramarino)", que cierra España, aparta de mí estos premios (Iwasaki 2009b: 155-157), y que contrapuntea con el "Decálogo del perfecto cuentista" de Horacio Quiroga, Iwasaki aprovecha para volver a ironizar sobre su destino de escritor: "Los cuentos que envíes a los concursos nunca serán importantes para la historia de la literatura. En realidad, ni siquiera para la literatura" (155). En el punto vIII incluso parece reírse de lo que él mismo parece estar haciendo en sus propias obras:

No trates de impresionar a nadie, pues todos los jurados han leído a Joyce, Mann, Faulkner, Proust y Nabokov. Últimamente están leyendo también a Paul Auster. No obstante, si quieres parecerles un marciano, cita a Jardiel, Cunqueiro, Camba y Wenceslao. En una de esas, cuela. (Iwasaki 2009b: 156-157)

En Mi poncho es un kimono flamenco, Iwasaki narra toda una serie de anécdotas humorísticas, de corte claramente autoderrisorio, ya que lo presentan como un escritor marginal y periférico. Tal es el caso de la anécdota que lo presenta en un sitio tan minoritario como la Feria del Libro de Huelva, donde sólo firmará, además, un libro que ni siquiera es suyo, pues lo confundirán con Kazuo Ishiguro, cuya novela Un artista del mundo flotante tendrá que acabar firmando (2005a: 44). A continuación, Iwasaki se describe en Sevilla, donde un paseante lo felicita por sus artículos, aunque no por su calidad literaria, sino, simplemente, "por lo bien que has aprendido a escribir en español" (2005a: 44). Algo semejante sucede en el artículo periodístico "O escribes o pintas", recopilado en Una declaración de humor, donde se encuentra con problemas a la hora de realizar la declaración de hacienda, pues ignora "cuál era el epígrafe del Impuesto de Actividades Económicas que me correspondía como escritor", y al no encontrar uno satisfactorio acaba declarando como si fuese pintor (2012b: 85).

Otra estrategia para presentar como algo risible su presunto destino de escritor fracasado es identificarse con autores minoritarios y olvidados como, por ejemplo, Félix del Valle: "Hace un momento he citado a Mario Vargas Llosa, pero con quien me identifico en realidad es con el último Félix del Valle, ese peruano que escribía en Buenos Aires sobre Andalucía" (2005a: 43). Cuatro páginas más adelante, Iwasaki vuelve a repetir que lo más probable es que "mi exilio final sea el olvido, como el del escritor Félix del Valle" (2005a: 48). Lo cierto es que dicho motivo será tan importante para Iwasaki que será el principio estructurador de un libro como Nabokovia peruana, donde recogerá noticias de "escritores peruanos desleídos y olvidados" (2011: 13). El mismo autor presentará dicha actividad de arqueología literaria como una de las formas del autorretrato: "no creo que sea casual que los peruanos que he rastreado sean escritores preteridos, transterrados y extraterritoriales, pues hace años que he asumido que la suerte de esos peruanos desleídos prefigura el destino de mi propia obra" (2011: 131). A eso apunta, precisamente, el título del epílogo, "Nota bibliográfica (¿o 
autobiográfica?)" (129), que viene encabezado por un epígrafe de Oscar Wilde, que resume este peculiar proyecto literario -"The highest, as the lowest, form of criticism is a mode of autobiography", The Picture of Dorian Gray-, así como por una caricatura del autor. De algún modo, nuestro autor estaría reconvirtiendo el conocido consejo kafkiano de escribir como si estuvieses muerto en el consejo iwasakiano de escribir como si fueses un escritor olvidado.

Quizás valga la pena señalar que esta excentricidad literaria se nos muestra estrechamente conectada con su excentricidad nacional en el capítulo "Los españoles apócrifos", de su temprano libro de ensayos titulado El descubrimiento de España:

\begin{abstract}
Acaso inducido por mi propia condición de apátrida, no he conseguido ser indiferente a la suerte de aquellos escritores que por haberse apartado de mi país no cuentan para las letras peruanas, y que por haber sido extranjeros nunca contaron en la tradición literaria de los países que les acogieron. Y ya que me encontraba en España, decidí aplicarme en rebuscar trasteros y catálogos, con la esperanza de hallar la obra proscrita de esos peruanos inverosímiles, españoles apócrifos como yo. (Iwasaki 1996: 120)
\end{abstract}

Este tipo de burlas hacia su propio destino como escritor pueden adoptar formas más disimuladas. Tal es el caso, por ejemplo, de la primera frase de $E l$ descubrimiento de España, que es, claramente, una cita rebajada retóricamente de la primera frase de Cien años de soledad: "Muchos años después, ante un lienzo de Sorolla o en alguna de las playas de Huelva, recordé que la serena mirada de la madre Paloma fue para mí la primera sensación azul de España" (1996: 13). Este trabajo de autoderrisión literaria, que consiste en la escenificación de una supuesta mediocridad literaria, es también evidente en el epílogo de Ajuar funerario, donde el autor parece querer cerrar, con un juego de palabras, todo tipo de trascendencia literaria: "Una periodista me preguntó una vez si las breves historias de Ajuar funerario podían ser píldoras contra el miedo. No. En realidad son supositorios de terror" (2009a: 138).

Acabemos este apartado señalando que la "autoderrisión identitaria" practicada por Fernando Iwasaki también se ha centrado en su identidad en tanto que historiador. Tal es el caso, por ejemplo, del siguiente fragmento de la "Abjuración final" con la que se cierran Inquisiciones peruanas:

Descubrí la mayoría de estos procesos investigando para una tesis doctoral que nunca presenté, aunque entonces me pareció que carecían de toda importancia histórica y académica. Sin embargo, como después yo tampoco tuve ninguna importancia histórica y académica, me hizo ilusión dedicarles un desagravio risueño y literario. (Iwasaki 1994: 119-120)

Lo cierto es que, a pesar de las falsas protestaciones de intrascendencia que haya podido realizar en ciertas ocasiones, la "autoderrisión identitaria" practicada por Iwasaki tiene una clara función liberadora. Recordemos que todas estas prácticas autoderrisorias o autodeprecativas entroncan, consciente o 
inconscientemente, con un programa filosófico, o psicagógico, que busca humillar al ser humano con el objetivo de liberarlo de las pretensiones excesivas, las falsas esperanzas, el miedo, la culpa, el falso conocimiento, la inautenticidad o el puritanismo (sexual, político o identitario). Todas estas "pasiones tristes" apartarían al hombre de la única felicidad, modesta y terrenal, a la que puede aspirar en vida.

No es extraño, pues, que, en el primero de los ensayos incluidos en $\mathrm{Mi}$ poncho es un kimono flamenco, Iwasaki realice una reivindicación epicúrea del acto de escritura, que entiende como ejercicios de autobiografía ficticia que tienen como objetivo exorcizar las "pasiones tristes", por utilizar la terminología de Spinoza, en aras del goce y de la alegría: "Uno quiere reivindicar aquí y ahora la felicidad de leer y escribir, la alegría de contar y la dicha de comentar. ¿Qué me lleva si no a recrear mi infancia, confesar mis fracasos amorosos o compartir mi sentido del humor, si no es la necesidad de gozar?" (2005a: 18). Pocas páginas más adelante, el autor volverá a insistir en el fin hedonista que persigue toda su obra: "Quiero hacer hincapié en el placer, pues para buscarse problemas ya están los críticos y los profesores universitarios que practican el acoso textual" (21). Debemos tener, en cuenta, sin embargo, que el término "hedonismo" tiene un significado mucho más profundo, y para lo que nos interesa ahora, más profundo políticamente hablando que el que normalmente se le suele atribuir. Ciertamente, tras más de dos milenios de calumnias y deformaciones, es habitual concebir el hedonismo como una persecución irracional e irresponsable de placeres meramente físicos. Aunque no es este el lugar para realizar una reconstrucción del término ${ }^{22}$, quizás podamos señalar que, aunque Epicuro, Lucrecio y Montaigne no desarrollaron las implicaciones políticas que la ética hedonista o epicúrea encerraba, sí lo hizo Spinoza en su Ética y, sobre todo, en su Tratado teológico-político. Para Spinoza, el gobierno tiránico busca exacerbar las "pasiones tristes" (el odio, la envidia, la vergüenza, la tristeza, la melancolía, el miedo, el arrepentimiento, la desesperación, la decepción, la venganza o el sometimiento), por la sencilla razón de que estas debilitan a los hombres y los hacen más fácilmente dominables; mientras que el buen gobierno trata de fomentar las "pasiones alegres" (el orgullo, la seguridad, la admiración, la confianza, la risa, la curiosidad, el reconocimiento, la creatividad, la esperanza, la misericordia o la alabanza), precisamente porque la felicidad de los ciudadanos, aunque sea en detrimento de su propio poder, es su último objetivo ${ }^{23}$. Desde esta perspectiva, se nos hace más fácil comprender las virtudes ético-políticas, además de las cognoscitivas y existenciales, que estudiamos antes, del humor, en general, y de la autoderrisión, en particular.

\footnotetext{
22 Véase al respecto los cuatro primeros tomos de la Contrahistoria de la filosofía de Michel Onfray (2007a, 2007b, 2009, 2010).

${ }^{23}$ Traté este tema, junto a María Dolores Adsuar, en la ponencia titulada "Ampliación del campo de batalla: Un replanteamiento de la literatura española contemporánea a la luz de la filosofía política spinoziana", presentada en el XIV Congreso de literatura española contemporánea, Universidad de A Coruña, 17-21 de junio de 2013.
} 
Como era de esperar, Fernando Iwasaki es plenamente consciente de la importancia de la autoderrisión para estimular las "pasiones alegres" que persigue todo proyecto de corte emancipador. Y es que si, como decíamos más arriba, el dogmatismo identitario no solo genera ansiedad en los individuos, sino también fanatismo en las colectividades, es normal que el efecto terapéutico del humor, que para Iwasaki debe tener siempre un componente autoderrisorio, tenga también una dimensión política. No es extraño, pues, que en medio de un artículo periodístico, de corte humorístico, como "¿lgualdad de oportunidades genéticas?", recogido en Una declaración de humor, realice una afirmación del siguiente tipo: "Hablo de tolerancia, conocimiento y responsabilidad, valores que uno va adquiriendo a lo largo de la vida y que jamás alcanzaremos de manera absoluta. Hablo de amor, ternura y amistad, sentimientos que hacen a unos mejores que otros" (2012b:25).

Asimismo, en rePublicanos, un ensayo de tema histórico influido por el humorismo inteligente y alegre de la Historia de Inglaterra de Gilbert Keith Chesterton ${ }^{24}$, Fernando Iwasaki volverá a realizar una defensa de la promiscuidad identitaria no ya solo en términos existenciales, sino también colectivos: "no hay antídoto más eficaz contra la xenofobia -racial o ideológica- que el cruce sabroso, la mezcolanza multicultural y el ayuntamiento de toda la vida; o sea, sin connotaciones políticas" (2008: 132). Evidentemente, esta negación de las "connotaciones políticas" no se contradice realmente con el carácter político de la propuesta de Fernando Iwasaki, que implica luchar "contra la xenofobia -racial o ideológica-". Esta apariencia de contradicción, que es uno de los modos de la paradoja, se basa en la variedad de usos de los que es susceptible el término "política". De lo que no cabe duda es de que el "cruce sabroso" que Iwasaki propone en Mi poncho es un kimono flamenco, donde según afirma con felicidad en el prólogo "el humor y no la guerra" (2005a: 14), quiere operar cambios a un nivel colectivo, esto es, cambios políticos. Se trata de difundir "un pensamiento laico" (2008: 199) frente al carácter religioso de la religión, el nacionalismo o las ideologías. Sin embargo, la difusión de un pensamiento laico exige, a su vez, una "pedagogía laica" (119), esto es, serena, pacífica, tolerante, autocontenida y respetuosa; cosa que solo puede lograrse con un punto de autoderrisión.

Ciertamente, reírse de uno mismo, mostrar a la luz los propios defectos o contradicciones, es un excelente antídoto contra la tentación de la intolerancia, de la imposición y del desprecio. El mismo Erasmo cifraba el éxito de su proyecto de reforma religiosa, lo que en ese momento era decir también reforma política, en la capacidad de confesar los propios defectos con la esperanza de generar un ambiente de amicitia que propiciase el diálogo y la comprensión:

Todos nosotros nos reprochamos recíprocamente nuestra manera de vivir y nuestra doctrina. Nadie se dedica a corregir sus defectos. En los demás calum-

\footnotetext{
${ }^{24}$ Nótese por el siguiente fragmento la importancia que Iwasaki le confiere al humor dentro del género ensayístico: "[Valoro a] los apóstoles que predican el humor al prójimo a través de sus cuentos y novelas, aunque valoro más a quienes hacen el humor desde la crónica, el ensayo y las memorias" (Iwasaki 2012b: 9).
} 
niamos incluso lo que tienen de bueno, en nosotros no hay nada para lo que no encontremos disculpas. Que de la lengua que confiese venga, pues, el inicio de la restauración de la concordia. (Elogio de la lengua o Lingua, sive de linguae usu et abusu, 1525).

Uno de los máximos representantes de esa lengua o estilo que se confiesa, y que tiene un indudable elemento autoderrisorio, fue Michel de Montaigne. El autor de los Ensayos, que fue educado por un padre que intentó seguir al pie de la letra las recomendaciones del Plan de estudios (1511) de Erasmo, no tendrá reparos, en sus Ensayos, a la hora de hablar de su calvicie, de su impotencia, de su tacañería, de su mala memoria o, incluso, del tamaño de su pene ${ }^{25}$. El mismo espíritu reina en obras como el Lazarillo o el Quijote, donde Sancho Panza se hace eco de las recomendaciones erasmistas al afirmar aquello de: "cada uno meta la mano en su pecho, y no se ponga a juzgar lo blanco por negro y lo negro por blanco; que cada uno es como Dios le hizo, y aun peor muchas veces" (I, iv).

Sería un error considerar que el erasmismo es una corriente filosóficoliteraria alejada de los intereses de Fernando Iwasaki. El siguiente fragmento, extraído de rePublicanos, muestra lo contrario:

De hecho, a veces, cuando pienso en la famosa pregunta que se formuló Vargas Llosa en Conversación en La Catedral (1968) - ¿En qué momento se había jodido el Perú?"-, creo que España y América Latina se jodieron cuando los erasmistas fueron censurados, perseguidos y procesados por la Inquisición española. (Iwasaki 2008: 25)

Iwasaki coincidiría con Jorge Edwards, quien, en La muerte de Montaigne, se propone recuperar el espíritu filosófico, religioso, literario y político de Erasmo y Montaigne, del que Latinoamérica y España fueron privados por culpa de la Contrarreforma y sus sucesivos avatares, y que habría supuesto un grave lastre político que perdura hasta nuestros días ${ }^{26}$. La obra de Iwasaki sabe crear ese ambiente de amicitia mediante este tipo de confesiones autoderrisorias. Así, en el "Colofón" que cierra El descubrimiento de España, donde ha criticado el carácter excesivamente subvencionado de la cultura española, el autor confesará: "A modo de colofón, debo decir que me he dejado querer por un par de ministerios y que ahora también soy ciudadano español" (1996: 203). Asimismo, en el capítulo titulado "El pensamiento de hortera y cassette", incluido en ese mismo libro, Iwasaki sugerirá haber sido también rehén de la sensiblonería hortera, siguiendo el consejo sanchopancesco de mirar el propio pecho:

Mas si el hipócrita y el bucólico lector sonríe meditando que estas líneas no le alcanzan, le exhorto a que mire sin pudor los ceniceros de su casa, al pato de murano que empolla sus huevecillos de ónice sobre una mesa de madera

\footnotetext{
25 Sobre las relaciones de esta actitud y la parresía o franqueza cínica, véase Diógenes Laercio (VI, ii, § 34, 151): "Preguntado qué es lo mejor en los hombres, respondió: 'La libertad en el decir"', y García Gual (1996: 9-87).

${ }^{26}$ Véase al respecto Castany Prado (2012b: 75-94) y Castañón (1998: 88).
} 
repujada, o a la manada de ciervos que trota por el bosque del cuadro más ecológico del salón. Entonces comprenderá que no hay escapatoria posible, porque aquel que crea estar libre de horteradas, que arroje el primer cassette de Silvio Rodríguez. (Iwasaki 1996: 152)

\section{CONCLUSIÓN}

Algunos autores ven en la autoderrisión una "pendiente" que puede llevarnos a la "apología cínica de la desesperanza" y en la "transformación del saludable pesimismo de la razón en la abdicación de la voluntad" (Bouquet y Riffault 2010). Seguramente, este tipo de advertencias están influidas por la campaña de demonización de la risa llevada a cabo por una corriente intelectual, que podríamos llamar agelástica, recordando a Rabelais, asociada normalmente a las esferas de poder, y que consideraría que la comicidad es peligrosa por su carácter incontrolable e irrespetuoso. Es cierto, sin embargo, que la posmodernidad fue incapaz de elaborar una visión "trascendente" de la comicidad, dándole inadvertidamente la razón a aquellos que la criticaban como expresión de nihilismo. No es ese el caso de Fernando Iwasaki, cuya comicidad tiene una fuerza depuradora, liberadora y, en el mejor sentido de la palabra, humillante o kenótica. Como intentamos mostrar en la primera parte de este trabajo, la obra de Iwasaki se inscribe, consciente o inconscientemente, en una milenaria tradición autoderrisoria, que usaría la autoficción autodeprecativa como "ejercicio espiritual", gracias al cual el hombre llegaría a conocerse y a aceptarse a sí mismo, en tanto que ser limitado, logrando, de este modo, una gozosa instalación en el aquí y ahora, así como una reconciliación con sus semejantes y con la vida.

\section{OBRAS CITADAS}

Adsuar, Maria Dolores, y Castany Prado, Bernat (2013): "Ampliación del campo de batalla: Un replanteamiento de la literatura española contemporánea a la luz de la filosofía política spinoziana". Ponencia presentada en el xIV Congreso de literatura española contemporánea, Universidad de A Coruña, 17-21 de junio, en prensa.

Aurelio, Marco (2005): Meditaciones. Madrid, Gredos.

Berger, Peter (1999): Risa redentora. La dimensión cómica de la experiencia humana. Barcelona, Kairós.

Bergson, Henri (2008): La risa: ensayo sobre la significación de lo cómico. Madrid, Alianza. Borges, Jorge Luis (1999): Obras completas, 4 vols. Barcelona, Emecé.

— (2003): Textos recobrados. 1956-1986. Barcelona, Emecé.

Bouquet, Brigitte, y Riffault, Jacques (2010): L'humour dans les diverses formes du rire. París, Vie Sociale.

Castany Prado, Bernat (2012a): "Literatura antipatriótica", Quimera. Revista de literatura, n. ${ }^{\circ}$ 348, pp. $12-19$.

- (2012b): "Los Ensayos de Montaigne como proyecto político en La muerte de Montaigne de Jorge Edwards", Revista chilena de literatura, n. 82 , pp. 75-94. 
- (2012c): Que nada se sabe. El escepticismo en la obra de Jorge Luis Borges. Alicante, Cuadernos de América Sin Nombre.

Castañón, Adolfo (1998): "La ausencia ubicua de Montaigne", Vuelta, n. 261, pp. 86-88.

Cerf, E. (1994): "Autodérision et idéologie: Jean du Trou aux Moustiques entre 1939 et 1945", Revue des Sciences Sociales de la France de l'Est, n. ${ }^{\circ} 21$, pp. 22-25.

Cornejo Polar, Antonio (1998): "Profecía y experiencia del caos: la narrativa peruana de las últimas décadas". En: Karl Kohut, José Morales y Sonia Rose (eds.): Literatura peruana hoy. Crisis y creación. Frankfurt, Vervuert.

Epístolas Pseudodiogénicas. En: VV.AA. (2008): Los filósofos cínicos y la literatura moral serioburlesca. Ed. de José A. Martín García, 2 vols. Madrid, AKAL, pp. 391-429.

Freud, Sigmund (2000): El chiste y su relación con el subconsciente. Madrid, Alianza.

García Gual, Carlos (1996): "La secta del perro", prólogo a Diógenes Laercio. En: Vidas de filósofos ilustres. Los cínicos. Madrid, Alianza, pp. 9-87.

Greiner, Bernhard (1992): Die Komödie. Tübingen, Francke.

Hadot, Pierre (2006): Ejercicios espirituales y filosofía antigua. Madrid, Siruela.

Iwasaki Cauti, Fernando (1988): Nación Peruana: entelequia o utopía. Lima, Crese.

— (1994): Inquisiciones peruanas. Madrid, Páginas de Espuma.

- (1996): El descubrimiento de España. Oviedo, Ediciones Nobel.

- (2001): Libro de mal amor. Barcelona, RBA.

- (2005a): Mi poncho es un kimono flamenco. Lima, Sarita Cartonera.

— (2005b): Neguijón. Madrid, Alfaguara.

_ (2007): Inquisiciones peruanas. Madrid. Páginas de Espuma.

- (2008): rePublicanos. Madrid. Algaba Ediciones.

- (2009a): Ajuar funerario. Madrid, Páginas de espuma.

- (2009b): España, aparta de mí estos premios. Madrid, Páginas de Espuma.

- (2011): Nabokovia peruviana. Sevilla. Ediciones La Isla de Sistolá.

- (2012a): Helarte de amar. Madrid, Páginas de Espuma.

- (2012b): Una declaración de humor. Logroño. Pepitas de calabaza.

Johnson, Paul (2012): Humoristas. Barcelona, Ático de los libros.

Kierkegaard, Sören (2008): Johanes Climacus o De todo hay que dudar. Barcelona, Alba.

- (1992): The Concept of Irony, with Continual Reference to Socrates. Princeton, Princeton University Press.

Laercio, Diógenes (1998): Vidas de los filósofos más ilustres. México, Porrúa.

Martin, R. P. (2000): "El acento escita: Anacarsis y los cínicos". En: R. Bracht Branham y M. O. Goulet-Cazé (eds.): Los cínicos. Barcelona, Seix Barral, pp. 182-207.

Medjahed, Lila (2005): "Autodérision et écriture dans les deux romans de Azouz Begag: 'Les Chiens aussi' et 'Dis Oualla!'", Insaniyat, n. ${ }^{\circ} 29-30$, pp. 145-158.

Morris, Desmond (2003): El mono desnudo. Madrid, Debolsillo.

Nezri-Dufour, Sophie (2000): "Primo Levi: rire pour ne pas pleurer", Italies, n. ${ }^{4}$, pp. 169182.

Onfray, Michel (2007a): Las sabidurías de la antigüedad. Contrahistoria de la filosofía, I, Barcelona, Anagrama.

- (2007b): El cristianismo hedonista. Contrahistoria de la filosofía, Il, Barcelona, Anagrama. - (2009): Los libertinos barrocos. Contrahistoria de la filosofía, III, Barcelona, Anagrama. 
- (2010): Los ultras de las Luces. Contrahistoria de la filosofía, IV, Barcelona, Anagrama. Petrarca, Francesco (2010): La meva ignorància i la de molts altres. Adesiara, Barcelona. Richter, Jean Paul (1991): Introducción a la estética. Madrid, Verbum.

Ritter, Joachim (1986): Subjetividad. Barcelona, Alfa.

Roelens, Nathalie (1996): "Egotisme et autodérision chez Stendhal: je tombe donc je suis", Dix-neuf/vingt: revue de littérature moderne, n. ${ }^{\circ}$ 2, pp. 27-70.

Stora-Sandor, Judith (2000): De Job a Woody Allen: el humor judío en la literatura. Buenos Aires, Biblos.

Toulmin, Stephen (2001): Cosmópolis. El trasfondo de la modernidad. Barcelona, Península. — (2003): Regreso a la razón. Barcelona, Península. 